\title{
FEASIBILITY OF CREATING A SPAWINING AND REARING CHANNEL TO THE MISSOURI RIVER USING THE LOWER DEEP CREEK DRAIN DITCH NEAR TOWNSEND, MONTANA
}

STATE DOCUMENTS COLLECTION

JUL 201992

MONTANA STATE LIBRARY
1515 E. 6th AVE.

HELENA, MONTANA 59620
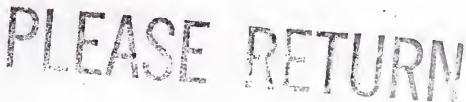



\title{
FEASIBILITY OF CREATING . \\ A SPAWNING AND REARING CHANNEL \\ TO THE MISSOURI RIVER \\ USING THE LOWER DEEP CREEK DRAIN DITCH \\ NEAR TOWNSEND, MONTANA
}

\author{
Prepared For \\ Montana Department of Fish, Wildlife and Parks \\ P.O. Box 262 \\ Townsend, MT 59644
}

November 25, 1989

Prepared By

INTER-FLUVE, INC

PO Box 773

Hood River, OR 97031

Beaverpond Plaza Suite 4

1665 Grant

1716 West Main Street

(503) $478-3035$

Bozeman, MT 59715

Denver, CO 80203

(406) 586-6926

(303) 839-1607 
-

-

。 


\section{INTRODUCTION}

An artificial spawning and reaning channel is under consideration by the Montana Department of Fish, Wildlife and Parks (FWP) as mitigation for the retrofitting and rehabilitation of the Toston Dam on the Missour River. The purpose of this study is to evaluate the suitability of using the downstream portion of the Lower Deep Creek Drain Ditch as such a channel. The Drain Ditch (as it will be called in this document for purposes of brevity) is a man-made channel which flows along the east and north edges of the town of Townsend, collecting irrigation return and spring water. The Drain ditch eventually empties into the East Side Supply Canal, which supplies water to the Canyon Ferry Dust Abatement Project.

\section{PARK EVALUATION}

\section{TOPOGRAPHIC SURVEYS}

The proposed site for the channel is located on Sections 19, 20 and 29; Township 7 North, Range 2 East, approximately one mile north of Townsend, Montana. On July 27 and November 7 , 1989, Inter-Fluve, Inc. personnel surveyed ground and water surface elevations in an area between the Sequoia Forest Industries lumber mill and the Missouri River (refer to plan drawing on Sheet 1). Surveys included water and channel bed elevations of the Drain Ditch within and immediately upstream of the lumber mill and the ground topography between the mill and the Missour River. This information was gathered to determine the amount of slope available for rehabilitation of the existing ditch and extension of the ditch to create a spawning/rearing channel.

The feasibility of this project rests almost entirely on whether sufficient slope is available to create appropriate conditions in a channel to provide spawning and rearing habitat. Available slope is dependent on the elevation difference between the starting point in the Drain Ditch and the ending point at the Missouri River. A buried culvert through the mill will dictate slope upstream and downstream of the mill. Since the water surface of the Missouri River varies widely with flow, feasibility considerations must also account for the effect of these variations on available slope.

Surveys indicate that the available slope for construction of a spawning/rearing channel is limited. Average slope through the lumber mill, between the ball park and the East Side Supply Canal, is less than $0.2 \%$. Slope between the mill and the river (at bankfull) is similarly limited at less than $0.1 \%$ (refer to profile drawing on Sheet 1). Given the small amount of slope between the river and the point where the Drain Ditch meets the East Side Supply Canal, when the Missour River is at flood stage the spawning/rearing channel would be inundated for a substantial distance.

\section{FLOW RECORDS}

The source of water for the spawning/rearing channel would be all that is collected in the Drain Ditch, augmented when and if necessary during extremely low flow periods. On April 11, 1989 representatives of FWP established a flume at the culvert where the Drain Ditch flows in to the East Side Supply Canal. Measurements were recorded daily until July 25; since then they have been taken on a bi-monthly basis. Since the last few years have been drought conditions, it is likely that the flows measured are representative of the lowest flows expected for creation of a spawning/reaning channel.

Measurements show that flows in the Drain Ditch are as high as $5 \mathrm{cfs}$. Monthly means vary between 3 and 4 cfs in April, May and July; only 1.6 cfs during June (Table 1). For both rainbow and brown trout, flows are sutficient to provide for passage of adults into the system, for spawning and for drift of juveniles out of the system. The only period when flows appear limiting is during the incubation period for rainbows (June). A well and pump system would likely need to be placed at the upstream end of the project (near the ball park) to augment flows during this period. 

Table 1. Discharge in cubic teet per second in Lower Deep Creek Drain Ditch at mill outflow into East Side Supply Canal, measured using a parshal flume.

\begin{tabular}{|c|c|c|c|c|}
\hline & APRIL & MAY & JUNE & JULY \\
\hline 1 & - & - & 3.7 & 0.0 \\
\hline 2 & - & - & 3.9 & 0.0 \\
\hline 3 & - & 3.7 & 3.7 & 0.9 \\
\hline 4 & - & 3.5 & - & 2.4 \\
\hline 5 & - & 2.2 & 2.2 & 2.8 \\
\hline 6 & - & 3.1 & 1.6 & 3.1 \\
\hline 7 & - & 3.2 & 1.6 & 2.4 \\
\hline 8 & - & 3.1 & 1.2 & - \\
\hline 9 & - & 5.7 & 1.2 & - \\
\hline 10 & - & 5.2 & - & 0.0 \\
\hline 11 & 1.6 & 4.0 & - & 2.8 \\
\hline 12 & 2.1 & 4.5 & 2.5 & 2.8 \\
\hline 13 & - & 4.3 & 1.3 & 4.3 \\
\hline 14 & - & 4.5 & 1.0 & 3.6 \\
\hline 15 & - & 4.9 & 1.0 & - \\
\hline 16 & 2.6 & 4.5 & 1.2 & - \\
\hline 17 & - & 3.6 & 1.4 & 2.8 \\
\hline 18 & - & - & 1.9 & 4.5 \\
\hline 19 & 3.9 & 3.6 & 2.2 & 4.5 \\
\hline 20 & - & 4.0 & 2.0 & 4.5 \\
\hline 21 & 3.9 & 3.5 & 2.0 & - \\
\hline 22 & 3.6 & 3.4 & 1.2 & - \\
\hline 23 & 3.5 & 3.5 & 0.0 & 4.8 \\
\hline 24 & 3.7 & 3.4 & 1.4 & 4.9 \\
\hline 25 & 3.8 & 3.4 & 0.6 & 4.8 \\
\hline 26 & 3.7 & 3.5 & 0.0 & - \\
\hline 27 & 3.5 & 3.5 & 0.8 & - \\
\hline 28 & 3.6 & 3.5 & 1.0 & - \\
\hline 29 & 3.5 & 3.8 & 0.9 & - \\
\hline 30 & 3.4 & 3.7 & - & - \\
\hline 31 & & 4.1 & & - \\
\hline Mean Flow & 3.3 & 3.8 & 1.6 & 2.9 \\
\hline Range in Flow & 1.6 to 3.9 & 3.1 to 5.7 & 0.0 to 3.9 & 0.0 to 4.9 \\
\hline
\end{tabular}


0

。

○ 
For the purpose of this document, a flow of $4 \mathrm{cfs}$ in the spawning/rearing channel was considered in order to estimate channel size, pump requirements and associated costs.

\section{WATER RIGHTS}

This feasibility study did not include a review of existing water rights on the water flowing within the Drain Ditch. It is likely that Sequoia Forest Industries and the State of Montana (through the Dust Abatement Program) hold some rights to the water. Regardless of the existing adjudications, a fish and wildlife beneficial use permit should be filed with the Montana Department of Natural Resources and Conservation (DNRC) if this project is implemented.

If a well is utilized to augment low summer flows in the Drain Ditch, a water right permit should also be filed with the DNRC.

\section{FEASIBILITY CONSIDERATIONS}

\section{LOCATION OF CHANNEL ALTERNATIVE}

Because of limited amount of slope within the Drain Ditch system, only one alternative appears feasible as a location for a spawning/rearing channel. This alternative utilizes the existing Drain Ditch channel through the mill yard, and thereafter follows a straight line to the river (refer to plan drawing on Sheet 1). These two sections differ significantly.

The upper section of channel, through the mill, presently suffers from lack of riparian vegetation and in places the streambanks are composed entirely of woodchips. Most slope is taken up in culverts under road crossings, or at partially blocked footbridges. In some portions it may be more cost-effective to build a new channel alongside the existing one rather than attempt to successfully remove the existing woodchip debris or narrow the channel to the appropriate width.

The lower section of channel, from the East Side Supply Canal to the Missouri River, does not yet exist, but would be aligned relatively straight from the mill outflow to the river.

\section{CHANNEL CONFIGURATION}

The physical dimensions of man-made spawning/rearing channels are largely dependent on three factors: habitat requirements of the target fish species, discharge and channel configuration. Habitat generally involves a combination of appropriate water depth, velocity and substrate. Discharge is either a controlled or is dependent on seasonal variation. Aspects of channel shape, such as channel wetted perimeter, hydraulic radius, sinuosity, meander wavelength and bedform variation, can be manipulated within the confines of the above factors. Gradient tends to be a deciding factor; it can be decreased but not increased. Typically, at a given discharge over a known slope, the plan and profile of the channel can be designed to provide appropriate water velocities and depths. In this case where slope in the Drain Ditch is minimal, proper water depths and velocities must be created by constricting the channel cross-section.

Slope can be adjusted within a reach of the channel by altering the percent composition of riffle and pools. In a man-made channel, as in natural channels, slope is not constant but varies over channel bedforms. That is, slope is higher over riffles and lower over pools and runs. By increasing the percentage of pools and runs, the slope available for riffles increases. By varying the total length of riffles in a channel, the available slope over the riffles can be adjusted to meet fish habitat requirements. The percentage of riffles to pools and runs can also be adjusted to create the appropriate ratio of spawning to rearing habitat.

Based on Inter-Fluve's construction of similar spring-fed natural channels where spawning by rainbow and brown trout has occurred the slope over a riffle should be approximately $1 \%$. A slope of $1 \%$ falls within the $0.5 \%$ to $1.5 \%$ range often used for artificial spawning channels. However, there are examples in the literature where antificial spawning channels for rainbow trout were 

constructed where slopes were $0.15 \%$. In some cases, slopes at $0.25 \%$ were considered too steep since spawning fish tended to move gravels quite a distance downstream. In contrast to the Drain Ditch, these projects used discharges 4 to 6 times higher and channel widths 2 times greater. In most all cases in the literature, the desired water depths and velocities over riffles were similar.

In the case of a channel associated with water from the Drain Ditch, where spawning habitat is to be provided for brown and rainbow trout and slope is limited; the slope over riffles will likely be between 0.2 and $0.4 \%$. The channel cross-section can be narrowed to maintain water depth and velocity, if frictional roughness is similarly adjusted.

\section{CHANNEL CROSS-SECTION}

The channel width, wetted perimeter and hydraulic radius can be manipulated to provide appropriate water depths and velocities based on available slope, as described in the previous section. Spawning habitat requires water velocities (at $95 \%$ probability of use) for rainbow trout between 1.3 and 2.2 feet per second and for brown trout between 1.4 and 2.2 feet per second. Similarly, water depths for rainbow trout are between 0.6 and 0.9 feet; brown trout are between 0.5 and 0.8 feet. The Manning equation was used to determine channel width, based on these velocities and depths over a riffle at $0.2 \%$ slope with a given roughness. Assuming an average discharge of 4 cubic feet per second, the channel would likely be about 5 to 6 feet wide.

\section{CHANNEL SUBSTRATE}

The existing Drain Ditch channel should be reconfigured, and the extension of the Drain ditch should be designed, to accommodate placement of gravel and cobble suitable for spawning, egg incubation and juvenile rearing. Round, screened, unwashed, non-crushed gravel and cobble varying in size from $1 / 2$ to 3 inches should be used. A range in sizes of gravel which includes material slightly larger than that observed over redds should be used, based on reports in the literature which describe particle distribution within redds. A moderate percentage of fine-sized material in the gravel mixture would be beneficial; it prevents too much water from flowing through the gravel relative to that flowing over.

It is not recommended that the channel be lined with an impermeable layer (synthetic or clay liner), seepage loss of water would be insignificant after fines transported in the Drain Ditch have an opportunity to fill interstices in the extension of the ditch (from the mill to the river). The site should be graded compacted along the alignment; such base preparation should minimize seepage loss.

\section{FLOW AUGMENTATION}

Records for the spring, summer and fall of 1989 indicate that flows would be suitable during most of the year except June, when discharge in the Drain ditch is negligible. A well could be drilled near the ballpark (on Bureau of Reclamation land) and ground water pumped to augment low flows. During June, rainbow spawning is completed and the primary consideration is keeping sufficient water over incubating eggs. Incubation would be successful with less flow than 4 cfs, meaning that a pump and well system would not be required to provide as much flow as would be required during spawning. For example, a flow of 2 or 3 cts would likely be sufficient. Flows could also be augmented during spawning periods (with 1 or 2 cfs) if flows in the Drain Ditch are low.

A well and pump would also benefit the lumber mill, as the water could be used for fire suppression during emergencies. A pump system would be more reliable during the June when fire danger is highest and water in the Drain Ditch is lowest. It would also be preferable than attempting to pump from a pond during winter when the surface was frozen.

\section{HABITAT FOA FISH}

While the emphasis of the project is creation of a spawning channel for rainbow and brown trout, one must also consider the need for habitat used by other fife stages. For example, the channel 
0

○

- 
should have a large amount of suitable spawning habitat, but it should also provide escape cover for adult trout in the form of deep pools and overhanging vegetation. The channel should also provide a large amount of rearing habitat for juvenile trout, such as shallow margins and interstices of large cobble.

\section{EROSION CONTROL AND RIPARIAN RE-VEGETATION}

Erosion control during and immediately following construction should be implemented. It is suggested that an organic fabric be used along the stream bank to prevent erosion. The woven coconut blanket C125 made by North American Green (phone 812-867-6632) or similar has proven to be suitable. Prior to fabric placement, all disturbed areas should be re-seeded with a grass mixture that includes predominantly native species with a fast-sprouting annual grain.

In additions, sections of the channel that flow through the mill will need to be protected from windblown wood chips and other mill debris. The least expensive method would be to provide a dense riparian corridor along both sides of the channel. In addition, a sediment control fence (Mirafi brand or similar attached to metal fence posts) alongside the corridor would supplement vegetative controls and would facilitate periodic cleanup. Since re-vegetation takes a number of years, a fence would act as primary control in the interim.

\section{EFFECTS ON EAST SIDE SUPPLY CANAL}

Since water from the Drain Ditch presently flows into the East Side Supply Canal, a headgate should be placed at the confluence to allow water to be diverted either into the canal or down the spawning/rearing channel. With this arrangement, excess or emergency flows can be used in the Dust Abatement Program.

\section{ESTIMATED COSTS}

Estimated costs for design and construction are listed in Table 2. Since design has not been completed, construction costs are based on those for similar stream reconstruction projects. In order to identify construction costs associated with particular items, the channel has been divided into upper and lower sections. Costs figures outline in Table 2 include all those for construction of a spawning/rearing channel. The table also includes costs in the upper section for the well and pump, additional pipe for fire suppression in the mill and pipe for road crossings. Cost figures for the lower section include a headgate at the East Side Supply Canal and a boulder or concrete fish ladder to allow passage into the channel during low flow in the river.

For both sections, design costs are estimated to be $\$ 10,300$ and construction costs $\$ 123,100$; the total cost for the project is estimated to be $\$ 133,400$.

\section{TIMEFRAME}

Design could occur at any time and will require 2 to 3 weeks to complete. However, applications for water rights may take 2 to 3 months depending on whether objections by other water users are filed. Therefore, design should commence well before construction is slated to occur.

Since there are no extreme flows in the Drain Ditch, construction of the spawning/rearing channel could occur during any time of the year, although low flow conditions would facilitate the process. Thus the best time for construction of the channel would be in June. The best time to work at the confluence of the channel and the Missouri River would be in July or later. 

Table 2. Estimated costs for design and construction of a spawning/rearing channel.

\begin{tabular}{cc}
\hline $\begin{array}{c}\text { GENERAL CHANNEL FEATURES } \\
\text { Channel Length (ft.) } \\
\text { Ball field to mill outlet } \\
\text { Mill outlet to river } \\
\text { Tota! }\end{array}$ & 2,800 \\
Channel Width (ft.) & 4,100 \\
Channel Surface Area (sq. ft.) & 5 \\
Average Gradient (\%) & 20,500 \\
Riffle (sq. ft.) & 0.1 \\
Riffle (\%) & 12,300 \\
Pool/Run (sq. ft.) & 60 \\
Pool/Run (\%) & 8,200 \\
Probable Riffle Utilization (\%) & 40 \\
Spawning Area (sq. ft.) & 30 \\
& 3,690 \\
\hline
\end{tabular}

UPPER SECTION: MILL CHANNEL

Estimated Design Costs

$\$ 6,800$

Estimated Construction Costs

Well and Pump $\$ 30,000$

Fire Suppression Pipe to Mill $\$ \$ 8,000$

Channel $\$ 33,600$

Road Crossings $\$ 1,000$

Erosion Control \& Revegatation $\$ \$ 11,200$

Construction Supervision $\$ 19,600$

Approx. Cost per Foot

$\$ 39$

Estimated Total Costs

$\$ 110,200$

\section{LOWER SECTION: CANAL TO RIVER CHANNEL \\ Estimated Design Costs \\ $\$ 3,500$ \\ Estimated Construction Costs \\ Channel $\$ 10,400$ \\ Control Works at Canal \\ $\$ 2,000$ \\ Fish Passage at River \\ Erosion Control \& Revegatation \\ Construction Supervision \\ Approx. Cost per Foot \\ $\$ 4,000$ \\ $\$ 5,200$ \\ $\$ 9,100$ \\ $\$ 26$ \\ Estimated Total Costs \\ $\$ 34,200$}

TOTAL: BOTH SECTIONS OF CHANNEL

Estimated Design Costs

$\$ 10,300$

Estimated Construction Costs

Well and Pump $\$ 30,000$

Channel $\$ 44,000$

Control Works at Canal $\$ 2,000$

Fish Passage Facilities $\$ \$ 2,000$

Erosion Control \& Revegatation $\$ \$ 16,400$

Construction Supervision $\$ 28,700$

Approx. Cost per Foot

$\$ 33$

Estimated Total Costs

$\$ 133,400$ 



\section{RECOMMENDATIONS}

The creation of a spawning/rearing channel using the Drain Ditch has several inherent limitations that make this project less than ideal. First, water supply must be augmented; second, topographic conditions limit slope; and third, the lumber mill in the center of the project contributes wood chips and other debris to the channel.

None the less, with proper design and construction these shortcomings can be overcome in order to create a stream channel which will provide spawning and rearing for rainbow and brown trout. While the beneficial effects of this project are not certain, rainbow and brown trout have utilized habitat in similar enhancement projects and there is no reason this project shouldn't be successful if correctly implemented and maintained.

Typically, trout may use such spawning/reaning channels in the first season following construction, but it often requires two or more years until the channel is completely "seasoned". For example, one or more annual life cycles must occur before a diverse benthic invertebrate community becomes established. And spawning trout often don't fully utilize habitat until a channel supports a population of juvenile fish. With this in mind, the channel should be productive two or three - years following construction. 
